\title{
O paradoxo
}

protestante e 0

condicionamento do

"espírito" capitalista

ocidental de tipo

moderno:

algumas observações

sobre o pensamento

\section{weberiano}

\section{Lucas dos Santos}

Andrade*

DOI: 10.11606/issn.2318-8855.v10i2p121-147

Resumo: Neste artigo, propõe-se investigar a obra "A ética protestante e o 'espírito' do capitalismo" através da chave do paradoxo protestante. Para tanto, buscaremos explorar os detalhes da obra a "ética protestante" e, ao longo da exposição, cotejar a análise, quando necessário, com outros textos escritos pelo autor a respeito da temática da ética econômica das religiões mundiais e de outros temas periféricos. De acordo com a nossa leitura, o paradoxo é ponto nodal para a compreensão da teoria do surgimento do capitalismo de tipo moderno e da própria modernidade. Parte desse fenômeno surgiu a partir da relação histórica estreita entre o abandono intramundano e a valorização da ascese do trabalho protestante que, mesmo não sendo condicionada por fatores econômicos, sedimentou o surgimento de uma forma moral valorativa dos valores que constituem a forma de dominação racional moderna.

Palavras-chave: História intelectual, História Moderna, Max Weber 


\section{artigos}

\section{O paradoxo protestante e o condicionamento do "espírito" capitalista ocidental de tipo moderno}

I.

'A ética protestante e o "espírito" do capitalismo', publicado primeiramente em duas partes entre 1904 e 1905 dentro das páginas da revista Archiv füv Sozialwissenschaft und Sozialpolitik e posteriormente de forma revisada em 1920 como parte do projeto inacabado "Ensaios reunidos de Sociologia da Religião", pode ser considerado como sendo o trabalho mais debatido de autoria do economista, sociólogo, jurista e historiador alemão Karl Emil Maximilian Weber, ou, como ficou mais conhecido: Max Weber (1864 - 1920). No entanto, o intelectual alemão não nos deixou duas edições de uma mesma obra, mas sim duas versões, sendo ambas acabadas e com as suas particularidades editoriais e importância própria". A "ética protestante" publicada e comercializada em formato de livro avulso após o falecimento do intelectual alemão, aos 56 anos, por mais de meio século foi baseada de forma integral na versão entregue ao seu editor pouco antes da sua morte em 1920. Por conta desse fenômeno, a primeira versão se manteve, por muitos anos, reclusa a um pequeno grupo de intelectuais que tiveram acesso às publicações de 1904 e 1905. É notável a presença, portanto, da segunda versão nas traduções que ganharam o mundo após a morte do autor; dentro deste enquadramento destacamos a famosa tradução feita em 1930 para o inglês feita pelo sociólogo Talcott Parsons (1902 - 1979)², que foi a base para outras, como no caso brasileiro das

\footnotetext{
${ }^{1}$ Tal fenômeno se tornou mais claro após a publicação, durante a década de 90 do século passado, da versão crítica da "ética protestante" que passou a copilar as duas versões dentro de uma mesma obra. Para mais informações vide os comentários da "Apresentação" da edição de centenário da Companhia das Letras, escrita pelo professor Pierucci (PIERRUCl, 2019 [2004], p. 7 - 15) ou o breve comentário presente nas páginas 186 a 189, do trabalho do professor Pierucci sobre o "desencantamento" indicado na bibliografia.

${ }^{2}$ A respeito da leitura que Parsons propôs da obra weberiana destacamos o segundo volume da obra "Estrutura da ação social", publicado no Brasil em 2010 pela editora Vozes. Para uma análise crítica da leitura da visão do sociólogo estadunidense destacamos a leitura do brasileiro Carlos Eduardo Sell
} 


\section{artigos}

\section{Lucas dos Santos Andrade}

primeiros traduções ${ }^{3}$.

Entre a publicação da primeira e a segunda parte da "ética protestante" o intelectual alemão viajou para a América do Norte a convite do Congresso de Artes e Ciências da Exposição Universal - também conhecida como Feira Mundial de St. Louis. Durante a estadia no novo continente, Weber observou em campo o modo de vida capitalista estadunidense, burocrático e racionalista, e, principalmente, a influência do ascetismo intramundano protestante na sua forma histórica atenuada: o puritanismo, mesmo que em seus últimos. Possivelmente, a experiência no novo continente deu a Weber maior solidez para o argumento que estava construindo. Esse fenômeno pode ser percebido na segunda parte da primeira versão publicada na Archiv em 1905 no destaque dado pelo autor às seitas protestantes como sendo, após Calvino, o principal conjunto religioso que contribuiu para o condicionamento do espírito capitalista. A influência da experiência estadunidense pode ainda ser encontrada em outros textos do autor, principalmente no artigo irmão da "ética protestante" editado no Brasil com o título "As seitas protestantes e o espírito do capitalismo" - publicado em alemão em 1906 nas páginas da Archiv e revisado em 19204.

Alguns dos conceitos, detalhamentos, comentários e descrições tipológicas

presente entre as páginas 23 e 25 da obra "Max Weber e a racionalidade da vida", publicado pela editora Vozes em 2013.

${ }^{3}$ A primeira e a mais célebre tradução do inglês para o português tomando por base a tradução de Parsons foi feita pelos sociólogos Maria Irene de Q. F. Szmrecsányi e Tamás Szmrecsányi. Atualmente é comum encontrarmos tradução da "ética protestante" traduzidas do inglês para o português, pois a tradução do sociólogo Parsons entrou em domínio público. Muitas dessas edições possuem "preço popular", mas carregam incongruências herdadas da versão em inglês.

4 Em português podemos encontrar a tradução desse artigo principalmente em duas versões. Primeiramente através de uma tradução do inglês presente no compêndio "Ensaios de Sociologia", organizado por H. H. Gerth e C. Wright Mills, com o título traduzido "As seitas protestantes e o espírito capitalista". Mais recentemente, em 2020, o artigo foi publicado como anexo a edição da "ética protestante" da editora Vozes diretamente da sua tradução alemão com o título "As seitas protestantes e o espírito do capitalismo" junto de outros textos do autor da época da primeira versão, como: "Igrejas e seitas na América do Norte" e as chamadas "Anticríticas". 


\section{artigos}

\section{O paradoxo protestante e o condicionamento do "espírito" capitalista ocidental de}

tipo moderno

presentes de forma nominal na segunda versão da "ética protestante" não podem ser encontrados na segunda e esse fenômeno contribuiu para a criação de verdadeiros anacronismos analíticos por parte dos comentadores da obra weberiana por praticamente todo o século XX. Dentro desse enquadramento, um dos conceitos que sofreu com as leituras anacrônicas e desorientadas foi o de desencantamento (ou "desmagificação"5); como consequência desta forma de leitura, acreditou-se que o conceito estava presente desde a primeira versão - tendo influenciado, portanto, teoricamente todos os outros usos subsequentes. Contudo, como aponta o sociológico brasileiro Antônio Flávio Pierucci e outros comentaristas atuais, o conceito de desencantamento só veio a ser cunhado e utilizado nominalmente cerca de oito anos após publicação da primeira versão (PIERUCCI, 2013, p.62) - sendo o uso do conceito dentro da segunda versão, portanto, uma particularidade da revisão.

De forma geral, os artigos de 1904 e 1905, podendo ainda ser acrescentado o artigo irmão de 1906, constituíram a primeira experiência expressiva do intelectual alemão no jovem campo da sociologia. Os trabalhos dessa primeira fase, propriamente ditos, influenciaram o crescente interesse do autor pelos estudos comparativos da confissão protestante com outros grandes tipos religiosos. Dentro desse cenário, os estudos posteriores às primeiras publicações permitiram o amadurecimento conceitual e argumentativo que observamos na segunda versão. Isso se deu, entre outros fatores, pois o objetivo do autor, em seus estudos sobre as diferentes formas confessionais subsequentes, era de refinar a exposição das

\footnotetext{
${ }^{5} \mathrm{O}$ primeiro uso do conceito de forma nominal encontra-se na publicação "Sobre algumas categorias da sociologia compreensiva", escrito possivelmente em 1912 e publica no ano seguinte. O texto em português pode ser encontrado com o título mencionado no compêndio "Metodologia das Ciências Sociais" - tanto em sua versão antiga publicada pela Cortez como na atual publicada pela Cortez em parceria com a Unicamp.
} 
Lucas dos Santos Andrade

particularidades do protestantismo ocidental que contribuíram para o surgimento do espírito capitalista proposto em 1904 e observado no mesmo ano durante a viagem do intelectual a América do Norte. Desde 1916, um ano antes da Grande Guerra, portanto, por exemplo, Weber passou a planejar um grande compêndio de sociologia religiosa compreensiva, abarcando em seu conteúdo parte do material publicado desde $1904^{6}$.

Contudo, por conta da guerra e das outras ocupações desempenhadas pelo intelectual, os planos passaram por um processo de desaceleração, necessitando esperar o fim da guerra e as negociações de 1919 para a retomada do fôlego intelectual. Infelizmente, no ano seguinte o intelectual adoeceu e morreu precocemente, deixando grande parte dos seus planos editoriais inacabados ou sem suas últimas revisões. No entanto, após 1920, Marianne Weber (1870 - 1954) ${ }^{7}$, buscou ao longo da sua vida após 1920, com o auxílio de outros intelectuais, terminar a editoração e a publicação de alguns dos projetos do seu esposo. Sempre é bom lembrarmos que grande parte do material a que temos acesso atualmente nasceu da empreitada de Marianne para a conservação e reprodução das ideias do marido ${ }^{8}$. A

\footnotetext{
${ }^{6}$ O compêndio em questão é o inacabado "Ensaios Reunidos de Sociologia da Religião". Em seu corpo, a obra abrigaria: "ética protestante"; "as seitas protestantes", os volumes que posteriormente foram publicados dentro da "A ética das religiões mundiais" e outros textos nunca iniciados pelo autor - como o estudo sobre o catolicismo e sobre o islamismo.

${ }^{7}$ A esposa do intelectual alemã foi uma importante feminista liberal durante a primeira do século XX. Da mesma forma, foi a primeira biografia e por muitos anos guardiã da herança intelectual do marido.

8 Muitos dos textos publicados postumamente foram anteriormente publicados oficialmente nas páginas da Archiv. No entanto, é conhecido o zelo que Weber mantinha pela coerência e por causa desse fenômeno muitos desses textos estavam passando por reescrita para futuras republicações quando o intelectual veio a falecer. Praticamente todos os compêndios que temos acesso atualmente foram publicados de forma póstuma e, muitas vezes, sem atentar para a coerência interna entre os textos. Dentre as obras póstumas mais prejudicadas por esse processo encontram-se "Economia e Sociedade", remontado de diversas formas ao longo dos seus cem anos de publicação, e o "Metodologia das Ciências Sociais" - que reúne textos extremamente heterodoxos quando observamos em conjunto.
} 


\section{artigos}

\section{O paradoxo protestante e o condicionamento do "espírito" capitalista ocidental de}

tipo moderno

segunda versão, portanto, originalmente estava alojada dentro do corpo do imenso empreendimento intelectual de sociologia religiosa compreensiva pensado por Weber em sua última década de vida. Por conta deste fenômeno, muito pouco observado ou mencionado, acreditamos que a leitura crítica da "ética protestante", principalmente em sua segunda versão, necessita ser feita respeitando pelo menos as intenções editoriais e intelectuais do autor. Dessa forma, a segunda versão de 1920, para alguns tipos de análise, necessita ser lida em conjunto com os outros trabalhos sobre ética econômica das religiões, pois, existia a intenção do autor de complementar as lacunas ou aprofundar as explicações através da sobreposição das análises (SELL, 2013, p. 61 $69)$.

II.

A "ética protestante", propriamente dita, inicia-se, em ambas as versões, com algumas observações feitas por Weber a respeito da sua própria época, ou seja: sobre os primeiros anos do século XX. De acordo com o intelectual alemão, era visível, através da observação das taxas estatísticas ocupacionais de países pluriconfessionais ocidentais, o predomínio protestante nos postos de proprietários do capital, assim como nas camadas superiores de mão de obra qualificada; isto se dava, notavelmente, nas posições de qualificações técnicas mais elevadas dentro das empresas e do comércio. No entanto, para o intelectual, este predomínio não poderia ser explicado ou entendido como o resultado causal do favorecimento de uma confissão religiosa por fenômenos estritamente econômicos e tampouco poderia ser entendido simplesmente pela relação de um cabedal patrimonial herdado (WEBER, 2005 [1904; 1920], p. 29). Para Weber, a lógica explicativa para o surgimento de um sistema capitalista massivo do tipo moderno atua de forma paradoxal e inversa 


\section{artigos}

\section{Lucas dos Santos Andrade}

àquela explicada de forma estritamente economicista, pois o objetivo primeiro dos "capitalistas" em sua fase heróica não estava sujeitado por questões econômicas, mas sim morais.

As confissões protestantes, de forma geral, conseguiram, por meio do jogo do acaso e não de forma teleológica, condicionar a base histórica ascético-confessional que deu o suporte para o desenvolvimento do paradoxo encontrado na contradição entre a rejeição do mundo (ou abandono) e o ascetismo intramundano importantes para o advento do capitalismo de tipo moderno. Contudo, válido reforçar, os objetivos dos protestantes e dos reformados não eram voltados para a implantação de um novo sistema econômico, mas sim atender a questões puramente religiosas, ou seja: a pregação das "boas-novas" e o meio de atingir a salvação.

A respeito da presença religiosa como condicionante econômico Weber desta que, no texto introdutório do compêndio "Ética econômica das religiões mundiais":

"Nenhuma ética econômica foi, jamais, determinada apenas pela religião. Mas, seja como for, nem por isso é menos certo que a determinação religiosa da conduta da vida também seja um - e notar bem: apenas um dos fatores determinantes da ética econômica" (WEBER, 2005 [1904; 1920], p. 20 - 21)

Portanto, em "ética protestante", Weber buscou se concentrar em apenas um fator determinante para compreender a formação do espírito do capitalismo de tipo moderno. Em outras obras sequentes o autor elevou ao posto de objeto de estudo fenômenos como a formação das cidades ou o surgimento do aparato burocrático (incluindo o meio jurídico) como elementos importantes para a consolidação do capitalismo e do moderno Estado Nacional - como podemos observar, por exemplo, 


\section{artigos}

\section{O paradoxo protestante e o condicionamento do "espírito" capitalista ocidental de}

tipo moderno

no compêndio "Economia e Sociedade" .

No entanto, os protestantes não foram os únicos que atingiram um grau elevado de disciplina intramundana e nem foram os únicos a desenvolverem certas características presentes no do processo histórico que condicionou o sistema de dominação racionalista presente no capitalismo de tipo moderno. De acordo com o brasileiro Carlos Eduardo Sell, a obra weberiana após a publicação da primeira versão da "ética protestante" - e principalmente após 1914 - concentrou-se na busca de compreender as diferentes formas de racionalidade historicamente produzidas em contextos confessionais distintos (SELL, 2013, p. 58; p. 102 - 105). Essa forma de leitura quebra parte do estereótipo de eurocentrismo que a obra weberiana carregou por décadas por valorizar outros contextos sócio-históricos. No entanto, a forma de dominação racional, como fenômeno singular, é uma característica encontrada por Weber apenas nas sociedades Ocidentais (WEBER, 2012 [1913; 1914], p. 416).

Entre os elementos presentes em outras formas confessionais que carregam racionalidades próprias, Weber destacou, por exemplo, a disciplina intramundana hinduísta que sedimentou o desenvolvimento de uma sociedade estritamente estratificada e um grau intramundano nunca alcançado pelos protestantes (WEBER, 2016 [1913; 1915], p. 361). Da mesma forma, os budistas antigos da região da Índia representam para Weber o maior exemplo de rejeição da vida intramundana por conta da prática do isolamento voluntário dentro de comunidades de membros plenos e intelectualizados - causando com isto o afastamento de praticamente todos os leigos do seu meio (WEBER, 2016 [1913], p. 22). Contudo, as religiões indianas não

\footnotetext{
9 Para mais informações vide, principalmente, o segundo volume da tradução brasileira publicado pela UnB - principalmente nos capítulos sobre a sociologia do direito (capítulo VII, p. 1 - 153) e a Seção 7 da análise extensa sobre a sociologia da dominação (capítulo IX, Seção Sete, p. 362 -408).
} 


\section{artigos}

\section{Lucas dos Santos Andrade}

conseguiram em seu processo sócio-histórico se desvencilhar da rigidez da sua estrutura social, dificultando, com isto, a formação de uma ética capitalista de tipo moderna. No caso indiano, de forma geral, o ascetismo e a rejeição do mundo atuaram de maneiras particulares no condicionamento dos tipos tolerados pela dominação e isso fez com que fossem geradas relações socioeconômicas próprias.

Outros casos notáveis explorados por Weber de forma comparativa são os das religiões da região da China, onde, mesmo existindo "políticas capitalistas" e "incentivo para a aquisição financeira", não houve a formação de uma mentalidade capitalista moderna (WEBER, 2016 [1920], p. 347; p. 354; p. 358). Para o caso chinês, de acordo com o intelectual alemão, faltou o desenvolvimento do processo de desencantamento do mundo. Dentro desse enquadramento, as castas burocráticas religiosas e livrescas moldavam o mundo conforme preceitos mágicos e isto sedimentava a formação de um perpétuo "jardim encantado" afastado de todo o racionalismo do tipo encontrado no capitalismo moderno (IDEM p. 336). Como resultado, o confucionismo se caracteriza como a religião estudada pelo autor que menos desvalorizou o mundo, adaptando-se no lugar de modificá-lo e permitindo a existência de relações familiares tradicionalistas em sua estrutura e gerando com isto o condicionamento de outro tipo de sistema socioeconômico único (PIERUCCI, 2013, p. 114 - 134).

No caso do judaísmo antigo, historicamente, de acordo com Weber, desde a sua fundação ocorreu a produção e a reprodução de relações sociais fortemente marcadas pelas atividades urbanas burguesas e este fenômeno permitiu o fortalecimento das vocações urbanas e comerciais para subsistência e mesmo para o enriquecimento (WEBER, 2016 [1913; 1915], p. 406). Outro elemento interessante no caso do judaísmo antigo foi o incremento racional da conduta da vida massiva através 


\section{artigos}

\section{O paradoxo protestante e o condicionamento do "espírito" capitalista ocidental de}

tipo moderno

da necessidade do conhecimento das escrituras por parte de todos os membros da comunidade religiosa - gerando, desta forma, uma massificação pouco comum entre as religiões mundiais e afastando a separação estamental rígida de outras grandes religiões. Contudo, por conta da sua reclusão do mundo por conta do estreitamente do convívio social, o judaísmo antigo não pode condicionar os elementos presentes no espírito do capitalismo moderno ocidental e se manteve como uma religião pária, com um capitalismo igualmente pária, sem forças para a expansão fora do seu cosmo social (WEBER, 2016 [1913; 1915], p. 404).

Se o protestantismo não foi o exemplo histórico de dominação que gerou de forma plena a restrição das relações sociais através da imposição de uma ascese intramundana, o tipo protestante foi aquele que alcançou maior coerência na combinação das restrições e na ascese individual. Parte da justificativa repousa no fato de que o protestantismo foi a única religião de grande porte que afastou e acabou com toda a magia do mundo (WEBER, 2012 [1913; 1914], p. 416). Evidentemente que esta conduta de vida não está ancorada exclusivamente no desencantamento; mas, por conta dele, os indivíduos passaram a não mais necessitar da sujeição mágica e passaram a dominar de forma extensiva o seu meio. Da mesma forma, a busca de uma vida coerente e racionalizada deu o condicionamento necessário para a formação de todo um aparato burocrático impessoal que, em alguns casos, consegue se autorregular e continuamente impõe certas restrições e liberações. A racionalização do mundo de forma coerente, de ponta a ponta, como sendo um fenômeno de dominação condicionado pelo desaparecimento da mágica do mundo é um produto importante e paradoxal para o próprio desaparecimento de todas as formas religiosas, por enquadrar os meios confessionais como sendo o resquício da irracionalidade do mundo (WEBER, 2016 [1913], p. 38 - 39). Reside neste 


\section{artigos}

\section{Lucas dos Santos Andrade}

ponto parte da explicação que podemos dar à afirmação que Weber faz em alguns dos seus trabalhos sobre o fim da participação ativa da religião no modo de vida ocidental - sobretudo no meio econômico, mas corroborando em todas as outras esferas (WEBER, 2016 [1920]. p. 335). As formas confessionais, sejam elas quaisquer, encontram nas restrições impostas pela necessidade de uma conduta de vida coerente e racional o enquadramento de inimigas do fortalecimento do capitalismo e dos valores do progresso e das lógicas desencantadas - como as ciências laicas.

Notemos bem que se outras religiões não puderam historicamente condicionar a formação de um espírito capitalista nada impede que elas assumam o espírito dentro das suas estruturas (WEBER, 2016 [1920], p. 359). Da mesma forma, o processo severo de desencantamento do mundo e da dominação das relações por meios racionais coerentes não afastou ou extinguiu totalmente a superstição do mundo (WEBER, 2016 [1920], p. 335). Dentro dessa chave, as superstições passam a assumir características parcialmente racionais para que a restrição imposta pela necessidade de uma vida coerente causem prejuízos menores - mesmo que nenhuma forma de superstição venha a ser plenamente racional. Importante destacar ainda que o intelectual alemão não era um apologista da racionalização do mundo, argumentando em muitos dos seus trabalhos que os meios irracionais são formas de retirar a plena dominação da conduta de vida racionalizada do mundo, desenvolvendo, desta forma, o encantamento para o mundo e para os Homens ${ }^{10}$.

\footnotetext{
10 Sobre a questão da irracionalidade como forma de "encantar o mundo" indicamos a leitura da passagem sobre a rejeição da esfera erótica (disponível em: WEBER, M. Religiões mundiais - Uma consideração intermediária (...). In: Ética econômica das Religiões Mundiais, vol. 1 (...). Ed. Vozes, 2016, p 387 - 395) e do seu respectivo comentário feito na conclusão do livro do professor Pierucci (disponível em: PIERUCCI, A. O Desencantamento do Mundo (...). São Paulo: Ed. 34, 2013, p. 215 - 221, ou mais precisamente no ponto sobre o erotismo como forma de encantamento entre as páginas 219 - 221). Weber também comenta a questão da castidade mágica (ou casamento) como fenômeno econômico e do erotismo como fenômeno extra cotidiano dentro do compêndio "Economia e
} 


\section{artigos}

\section{O paradoxo protestante e o condicionamento do "espírito" capitalista ocidental de}

tipo moderno

III.

De acordo com Weber, o fenômeno histórico da Reforma Protestante (1517 - 1648) marcou o momento em que não houve apenas a sedimentação da substituição de um tipo de dominação por outra, mas sim, de forma decisiva, o momento em que ocorreu a substituição de uma forma que praticamente não se fazia sentir efeitos nas relações sociais por outra, que passou a modificar de forma incômoda a conduta da vida. Pegando o exemplo do calvinismo, o autor argumenta que:

“(...) tal como vigorou no século XVI em Genebra e na Escócia, na virada do século XVI para o século XVII em boa parte dos Países Baixos, no século XVII na Nova Inglaterra e por um tempo na própria Inglaterra, seria para nós a forma simplesmente mais insuportável que poderia haver de controle eclesiástico do indivíduo" (WEBER, 2005 [1904; 1920], p. 35)

De forma geral, a consolidação de uma ética de vida que pudesse germinar historicamente o espírito capitalista moderno repousa na aparente contradição social condicionada pelo advento da Reforma Protestante - principalmente em relação ao par de fenômenos históricos caracterizados como: abandono do mundo ${ }^{11}$ e o ascetismo intramundano. Contudo, é errado pensarmos, como Weber destacou, que essa ética racionalizada da vida intramundana protestante, em seus primeiros dias, pregou questões modernas como progresso e mesmo a alegria do mundo gerada pelo espírito do trabalho - como ocorreu com os iluministas do século XVIII (WEBER, 2005 [1904; 1920], p. 38).

Sociedade" entre as páginas 400 a 402 da edição da UnB.

11 Outros termos correlatos para esse processo podem ser: rejeição do mundo ou estranhamento do mundo. 


\section{artigos}

\section{Lucas dos Santos Andrade}

A valorização do trabalho cotidiano como formadora do estado psicológico individual de autorrealização moral, para Weber, é um conceito novo que deve o seu aparecimento através de Lutero e da sua tradução da Bíblia (WEBER, 2005 [1904; 1920], p. 71). Contudo, a valorização em si não era um fenômeno inédito para os indivíduos europeus. Para o autor, a valorização do trabalho no período medieval pode ser observada, por exemplo, através dos escritos de Tomás de Aquino e a sua colocação do trabalho como: um fenômeno estritamente mundano, mas necessário. Esse enquadramento caracterizava o trabalho como um elemento moral para os escolásticos (WEBER, 2005 [1904; 1920], p. 73). Historicamente, outra forma de observarmos o sentimento de valorização do trabalho no período medieval se encontra nas críticas feitas a vida ascéticas dos monges e do seu desligamento com a vida comum - sendo taxados de egoístas por conta de tais práticas. Tanto a leitura escolástica como as críticas ao modo de vida monástico foram lidos e incorporados nas ideias dos primeiros reformadores. Dessa forma, o reformador Martinho Lutero (1483 - 1564) enquadrava o trabalho como sendo o reflexo da vontade de Deus, levando-o a pensar em uma teologia da destinação, unindo a questão do sustento com a escatologia primitiva.

Na leitura weberiana da obra de Lutero, o autor destaca que, a respeito da teologia da destinação:

“(...) o indivíduo deve permanecer fundamentalmente na profissão e no estamento em que Deus o colocou e manter sua ambição terrena dentro dos limites dessa posição na vida que Ihe foi dada (...)"

(WEBER, 2005 [1904; 1920], p. 76 - 77)

Deste modo, seguindo o raciocínio weberiano, Lutero não chegou a estabelecer 


\section{artigos}

\section{O paradoxo protestante e o condicionamento do "espírito" capitalista ocidental de}

tipo moderno

um princípio racionalizado para a questão do trabalho profissional - pelo contrário ${ }^{12}$. Da mesma forma, o reformador foi contra a cobrança de juros, a usura, ou mesmo uma vida que possa ser caracterizada modernamente como economicamente ativa. Parte da justificativa para essa forma de entendimento encontra-se nas bases teológicas luteranas que se concentravam em leituras bíblicas, sobretudo do Antigo Testamento, que buscavam respostas para questões primeiramente morais.

Lutero defendeu ao longo da sua vida ideias econômicas que podemos classificar como sendo do tipo tradicionalista e pouco racionalista em suas práticas. $\mathrm{O}$ ponto de vista econômico-teológico do reformador alemão, nas palavras de Weber, se ancorava principalmente no conceito de '(...) contente-se cada qual com seu "sustento" e deixe que os ímpios se lancem ao lucro - é este o sentido de todas as passagens que tratam diretamente da faina mundana' (WEBER, 2005 [1904; 1920]. p. 75). Dentro desse enquadramento, as ideias paulinas e as expectativas escatológicas dos cristãos primitivos fizeram parte da base da argumentação luterana. Dessa forma, o reformador pregava a indiferença à vida mundana (ou abandono do mundo) e a vigilância constante na espera da vinda do Dia do Juízo Final, mas afastando-se das ideias mágicas do catolicismo e dos místicos germânicos anteriores a ele. Portanto, Lutero buscou construir uma doutra teológica valorativa de um cristianismo primitivo, jogando as luzes da vida cristã na pureza da doutrina e na sua observação como sendo os únicos critérios da validação eclesiástica - não sendo, portanto, em vista de outros reformadores, um revolucionário propriamente dito, mas sim, de fato,

\footnotetext{
12 Weber destaca que, para Lutero: 'A vocação é aquilo que o ser humano tem de aceitar como desígnio divino, ao qual tem de "se dobrar" - essa nuance eclipsa a outra ideia também presente de que o trabalho profissional seria uma missão, ou melhor, a missão dada por Deus. E o desenvolvimento do luteranismo ortodoxo sublinhou esse traço ainda mais'; sendo que "(...) o desenvolvimento do luteranismo ortodoxo sublinhou esse traço ainda mais." (WEBER, 2005 [1904, 1920] p 77).
} 


\section{artigos}

\section{Lucas dos Santos Andrade}

um reformador (WEBER, 2012 [1913; 1914], p. 396) que através da sua obra deu forças para o advento de outros reformadores intensificarem o processo de desencantamento do mundo.

Ao lado de Lutero, Calvino representa para Weber uma peça importante para entendermos o movimento histórico de longa duração que condicionou a consolidação do espírito do capitalismo de tipo moderno e da nossa própria modernidade. Para o sociólogo alemão, a importância de Calvino repousa, principalmente, na sua tentativa de retirar todo o meio sentimental irracional luterano. Para tanto, o teólogo francês embutiu, mesmo inconscientemente, no protestantismo preceitos racionalizantes que marcaram de forma contínua a conduta de vida ocidental. A teologia calvinista pregou, dando continuidade ao pessimismo luterano, que o Homem, por conta do seu estado de pecado perpétuo, nas palavras do próprio Calvino:

“(...) perdeu por inteiro toda a capacidade de sua vontade para qualquer bem espiritual que o leve à salvação (...). Tanto que um homem natural, estando totalmente afastado desse bem e morto no pecado, não é capaz, por seu próprio esforço, de converter-se ou de preparar-se para tanto" (WEBER, 2005 [1905; 1920], p. 91)

Dentro dessa chave, no lugar das ações mundanas ou dos intermédios mágicos encontrados nos dogmas e na teologia católica como meio de salvação, o reformador francês pregou que apenas alguns indivíduos estão predestinados à vida eterna e à salvação e outros não e isto se dava por decreto do próprio deus. A salvação, portanto, não é algo que o Homem poderia conquistar pelas suas ações, mas sim por fatores que não estavam ao seu alcance - caracterizando assim a chamada teologia 


\section{artigos}

\section{O paradoxo protestante e o condicionamento do "espírito" capitalista ocidental de}

tipo moderno

da predestinação (WEBER, 2005 [1905], p. 92 - 93) $)^{13}$. Para os calvinistas, não era deus que existia para os indivíduos, mas sim o contrário - estando fora do entendimento humano qualquer decreto divino, a menos que fosse revelado pela vontade divina. $\mathrm{O}$ sentimento de rejeição do mundo gerado pela retirada das ações intramundanas mágicas e as boas práticas com objetivo atender as necessidades individuais de salvação - assim como o completo desconhecimento dos desígnios divinos ocultos jogaram os indivíduos em uma posição de desumanidade patética para Weber. Por conta desse sentimento os indivíduos sentiram pela primeira vez em sua história o abandono perpétuo

O mundo, portanto, para o cristão calvinista, ou reformado seguindo a nomenclatura weberiana, encontrava-se em processo de desencantamento e perda de sentido intramundano continuado. Entretanto, mesmo na rejeição do mundo em sua forma mais severa, como no caso do puritanismo, houve, para Weber, caminhos que, por mais estranhos e paradoxais que possam parecer, contribuíram para que a aproximação dos indivíduos existisse e se reproduzisse dentro da lógica de isolamento. Parte da explicação para essa contradição encontra-se na ideia da destinação do mundo como sendo um lugar para a glorificação de deus através do trabalho. Para Calvino o cristão eleito, mesmo sem saber se será salvo ou não, existe para servir a glorificação de deus e, reforça Weber na "segunda versão", apenas para isto. Esse preceito parte sumariamente do cumprimento dos desígnios revelados por deus aos indivíduos - devendo ser respeitado por conta da sua revelação divina. $\mathrm{O}$ trabalho social intramundano do cristão, nessa forma interpretativa teológica, era de

\footnotetext{
13 Weber destaca que Lutero anteriormente havia pensando em uma doutrina próxima a da predestinação; no entanto, por conta da sua atividade política, teve que se afastar das definições teológicas e se manter no exílio por um longo período.
} 


\section{artigos}

\section{Lucas dos Santos Andrade}

buscar continuamente aumentar a glória de deus, in majoren Dei gloriam, através das suas práticas cotidianas e não por meios ritualísticos ou sazonais.

A desigualdade humana, na lógica reformadora calvinista, foi entendida como uma característica natural e não sendo um empecilho para a aquisição dos bens da felicidade terrena (WEBER, 2012 [1913; 1914], p. 392); este fenômeno contribuiu, por sua vez, para parte do fim do sentimentalismo protestante de base luterana. Os indivíduos, portanto, passaram a ser compreendidos como ferramentas intramundanas de glorificação constante através das suas ações; sendo a vocação profissional, individual e continua, uma forma de obediência ao designo divino.

O ascetismo calvinista assegurava com sendo um dever psicológico se sentir um eleito, repudiando desta forma qualquer forma de dúvida. Essa certeza, contudo, deveria ser representada pela disciplina do dia a dia como forma de exercício subjetivo da própria eleição - gerando assim a auto inspeção constante do cristão em busca da conduta de vida esperada de um eleito de Cristo (WEBER, 2005 [1905; 1920], p. 105 - 106). Para os cristãos calvinistas, a vida que deveria ser buscada era aquela representada pelos cristãos dos tempos bíblicos, sobretudo do tempo do Velho Testamento, como modelo a ser alcançado. Desta forma, Weber destaca que, no lugar dos pecadores humildes, penitentes e sentimentais descritos por Lutero à procura da misericórdia pela fé, a disciplina calvinista formou santos autoconfiantes:

(...) com os quais toparemos outra vez na figura dos comerciantes puritanos da época heroica do capitalismo, rijos como aço, e em alguns exemplares isolados do presente' (WEBER, 2005 [1905; 1920], p. 102)

A eficácia da teologia calvinista, portanto, não repousa na coerência encontrada pelos cristãos na teologia confessional calvinista, mas sim pelos estímulos psicológicos que conseguiam atrair e aprisionar os cristãos de forma formidável. E 


\section{artigos}

\section{O paradoxo protestante e o condicionamento do "espírito" capitalista ocidental de}

tipo moderno

mesmo que Weber destaque que a confissão calvinista foi apenas uma das opções históricas dadas ele argumenta que essa forma de protestantismo conseguiu vencer, crescer e se reproduzir por conta dos fatores do condicionamento de uma racionalidade própria que restringiu a liberdade psicológica dos cristãos (WEBER, 2005 [1905; 1920], p. 116). No entanto, a adoção das ideias calvinistas de predestinação e a contradição instaurada pela ascese intramundana e pela rejeição do mundo foi lida e relida de diferentes maneiras pelas igrejas e seitas protestantes seguintes. À primeira vista, os casos limites podem nos parecer uma volta ao tipo de dominação tradicional ou carismática, mas, aos olhos de Weber, mesmo nos casos limites, configuram-se como exemplos onde a dominação racional encontrou-se de forma coerente. Dessa forma, após Lutero e Calvino, o terceiro segmento a que Weber deu destaque, nas duas versões da "ética protestante", para o condicionamento do espírito capitalista moderno é o encontrado nas seitas protestantes.

Dentro desse enquadramento, o intelectual alemão deu atenção especial aos anabatistas como os grandes portadores das ideias de ascese intramundana, principalmente os menonitas (ou mennonistas) e os quakers - comunidades religiosas cujo fundamento é por princípio heterogêneo à doutrina calvinista (WEBER, 2005 [1905; 1920], p. 130 - 131; nota n. 55). As seitas, para Weber, como tipos ideais, são organizações sociais condicionadas por uma dominação que não constituiu uma passagem plena por processos de racionalização da sua estrutura (WEBER, 2012 [191?], p. 158 - 167). Desta forma, a figura carismática do líder ou do profeta que traz novas revelações pode encontrar espaço dentro das estruturas comunitárias tradicionalistas. Entretanto, por conta do sentimento perpétuo de desencantamento do mundo protestante e o fim dos intermédios intramundanos de salvação e de 


\section{artigos}

\section{Lucas dos Santos Andrade}

relação com o deus cristão ausente, a figura do profeta ou líder encontraria na modernidade um forte bloqueio teológico para o seu predomínio; este fenômeno fez com que algumas seitas protestantes, chegassem ao ponto de abolir qualquer forma de liderança religiosa ou pedagógica por causa da falta da necessidade destas figuras para a obtenção da salvação e mesmo para o conhecimento religioso..

O rigor severo dos anabatistas que se fixaram no novo continente, em relação à autodisciplina e à busca da redenção individual, os condicionou para uma rejeição do mundo maior do que a encontrada entre os pietistas europeus e mesmo entre os calvinistas mais extremos. O afastamento da dogmática da autocracia bíblica e, por consequência, de todo o resquício de uma doutrina da salvação por via eclesiástica, chegou ao ponto, no caso dos quakers, do desaparecimento do batismo e da ceia como meios de manter a comunhão (WEBER, 2005 [1905; 1920], p 133). Desta forma, o rigor disciplinar aproximou cada vez mais as seitas anabatistas do novo continente do tipo puro das comunidades cristãs primitivas, tendo na condenação de toda a forma da divinização da criatura calvinista como um dos fundamentos principais da sua conduta de vida. De forma geral, portanto, os anabatistas do novo continente levaram o processo de desencantamento do mundo às suas últimas consequências históricas, transgredindo o racionalismo calvinista e colocando no lugar uma teologia da revelação continuada íntima entre os indivíduos e deus como sendo a única forma de compreensão das revelações bíblicas. O dom da graça, nesse enquadramento, precisava ser obtido através da vivência segundo uma consciência lícita e pura e apenas desta forma.

A espera perseverante dos anabatistas, no lugar da predestinação calvinista, 


\section{O paradoxo protestante e o condicionamento do "espírito" capitalista ocidental de}

tipo moderno

condicionou psicologicamente a moralidade ética dessas seitas ${ }^{14}$. No lugar do sentimento de rejeição intramundana pleno dos calvinistas, os anabatistas acreditavam na espera; cuja finalidade:

“(...) dessa perseverança, que deve ser silenciosa, é triunfar do quanto há de instintivo e irracional em cada um, triunfar das paixões e subjetividades do homem "natural"; por isso ele deve calar-se, a fim de criar na alma silêncio profundo, que só no silêncio Deus pode vir a falar" (WEBER, 2005 [1905; 1920], p. 134 - 135)

O silêncio anabatista, por sua vez, ajudou a contribuir claramente para a educação de uma ponderação serena da ação presente na vida profissional mundana - dentro e fora das comunidades. Ao contrário do que houve com os pietistas continentais, luteranos e mesmo com os calvinistas, os anabatistas do novo continente se voltaram para as práticas comerciais como forma tomista de desempenhar uma vocação inevitável ou mesmo natural - vocação essa: íntima entre os indivíduos e deus, mas mundana nas suas práticas, contudo, disciplinada e pura nas suas ações, assim como não aristocrática. A ética quaker, por exemplo, consistia no exercício ascético das virtudes profissionais; ou seja:

“(...) um consistente exercício ascético das virtudes, uma comprovação de seu estado de graça com base na conscienciosidade [sic] que se faz sentir no desvelo e no método com que ela se desincumbe de sua profissão". (WEBER, 2005 [1905; 1920], p. 147)

\footnotetext{
14 Weber destaca a questão da valorização da leitura do Livro de Jó por parte dos anabatistas. De acordo com intelectual alemão a respeito dessa prática: “(...) combina uma celebração grandiloquente da majestade absolutamente soberana de Deus pairando muito acima dos padrões humanos - o que, convenhamos, era totalmente congenial às concepções calvinistas - com aquela certeza, que rebenta novamente no desfecho do livro, de que Deus costuma abençoar os seus também e até mesmo [no Livro de Jó: - somente!] nesta vida, incluindo aí o aspecto material, ideia tão secundária para Calvino quanto relevante para o puritanismo" (WEBER, 2005, [1905, 1920], p 149 - 150).
} 


\section{artigos}

\section{Lucas dos Santos Andrade}

Ora, Weber destaca: não era o trabalho em si que era valorizado pelos quakers, mas sim o trabalho profissional racionalizado, ou seja, aquilo que o deus cristão exigia de forma atenuada. Essa caracterização fugiu da sorte da resignação luterana que era dada por deus e repousava na possibilidade vocacional, mas não de forma metódica e disciplinada como podemos encontrar nas seitas. Para a ética anabatista, representada pelos quakers no nosso exemplo, existia a possibilidade até então pouco comum e ausente no luteranismo das combinações de vários callings (ou: chamados) caso fosse favorável ao bem comum e o individual. Dessa forma, a utilidade de uma profissão, argumenta Weber:

'(...) se orienta em primeira linha por critérios morais e, em seguida, pela importância que têm para a "coletividade" os bens a serem produzidos nela, mas há um terceiro ponto de vista, o mais importante na prática, naturalmente: a "capacidade de dar lucro", lucro econômico privado' - não há dúvidas do que Weber estava destacando com esse trecho; caso não tenha ficado, podemos observar o complemento do trecho destacado: 'Pois se esse Deus, que o puritano vê operando em todas as circunstâncias da vida, indica a um dos seus uma oportunidade de lucro, é que ele tem lá suas intenções ao fazer isso. Logo, o cristão de fé tem que seguir esse chamado e aproveitar a oportunidade' (WEBER, 2005 [1905; 1920], p. 148)

Da mesma forma, a riqueza, dentro da ética quaker e dos anabatistas em geral, era:

“(...) reprovável precisamente e somente como tentação de abandonar-se ao ócio, à preguiça e ao pecaminoso gozo da vida, e a ambição de riqueza somente o é quando o que se pretende é poder viver mais tarde sem preocupação e prazerosamente. Quando porém [sic] ela advém enquanto desempenho do dever vocacional, ela é não só moralmente lícita, mas até mesmo um mandamento" (WEBER, 2005 [1905; 1920], p. 148) 


\section{artigos}

\section{O paradoxo protestante e o condicionamento do "espírito" capitalista ocidental de}

tipo moderno

Querer ser pobre - aqui vemos uma clara distinção entre o cristianismo romano (católico) e mesmo primitivo ou luterano - era o mesmo que desejar ser um doente para os quakers, ainda por cima, quem pede esmola - outra distinção importante com o sentimentalismo católico e luterano - estando apto a trabalhar não só estaria cometendo pecado da preguiça, mas também afrontava o designo do amor ao próximo.

Observando os detalhes da ética anabatista, podemos entender o porquê de Weber destacá-los como manifestação histórica importante para a genética do espírito do capitalismo de tipo moderno como o autor pode observar em 1904. Dentro desse enquadramento, por um lado, o puritano foi considerado pelo autor como sendo um verdadeiro administrador "(...) dos bens que the dispensou a graça de Deus (...)", devendo "(...) prestar contas de cada centavo [que the foi confiado] (...)" (WEBER, 2005 [1905; 1920], p. 155) e com isto estrangulando todo o tipo de consumo. Por outro lado, a ética "vocacional" religiosa de "fazer dinheiro"15 condicionou aquela outra - podemos acrescentar, laica - dos modernos capitalistas. Da mesma forma, os puritanos, através da sua rejeição do consumo e da ambição divina do lucro, geraram um certo tipo de acúmulo primitivo de capital diferente daquele presente no modelo marxista que consistiu, simplesmente, na '(...) acumulação de capital mediante coerção ascética à poupança' (WEBER, 2005 [1905; 1920], p. 157) - favorecendo e garantindo, portanto, o futuro investimento necessário para a implantação de um capitalismo do tipo moderno.

15 Weber chama os puritanos de "máquinas de produção de dinheiro" (WEBER, 2005 [1904; 1920], p. 155). 


\section{artigos}

\section{Lucas dos Santos Andrade}

IV.

A nível de conclusão é válido destacar que a aparente contradição paradoxal entre a rejeição do mundo e a disciplina ascética intramundana percorre, de forma geral, toda obra deixada por Weber - indo muito além das duas versões da "ética protestante". A aparente contradição para o intelectual alemão, não distanciou os cristãos das práticas e de uma ética ou moral mundana, mas sim o contrário: por conta do resultado irracional do paradoxo histórico formado. Válido destacar que, para o autor: “(...) talvez jamais haja existido forma mais intensa de valorização religiosa da ação moral do que aquela produzida pelo calvinismo em seus adeptos" (WEBER, 2005 [1905; 1920], p. 105 - 106). Para os calvinistas a ética mundana não estava ligada simplesmente com a questão da salvação, mas de uma vida regrada através do estreitamento das práticas de uma conduta de vida que refletisse individualmente a certeza da graça e da caracterização de ferramenta designada por deus para modificar o mundo em nome da glória divina. Dentro desse enquadramento, a ética condicionada pela dominação racional do ascetismo intramundano protestante (sobretudo calvinista e pós-calvinista) - por ter afastado todos os meios mágicos de obtenção da salvação e como intermédio da criatura com o criador - exigiu uma conduta de vida sumariamente individualista. Esse fenômeno condicionou a existência da necessidade de um contato direto entre o indivíduo e o deus cristão, assim como a busca individual constante da obediência dos desígnios divinos. Da mesma forma, condicionou a formação do tipo individuo-ferramenta cristão que deu sedimentou espaço para o outro tipo semelhante, mas laico e preso a um sistema burocratizado e racionalizado.

O racionalismo da ética intramundana protestante reformada repousa, portanto, na busca de uma vida ética e coerente de ponta a ponta em busca da 


\section{artigos}

\section{O paradoxo protestante e o condicionamento do "espírito" capitalista ocidental de}

tipo moderno

glorificação do criador, pois, nas palavras deixadas por Weber, “(...) jamais se levou tão a sério a sentença omnia in majoren Dedi gloriam" (WEBER, 2005 [1905; 1920], p. 106 - 107). Parte da qualidade do argumento de Weber está na severa observação do caráter puramente religioso dos preceitos e dos objetivos primários de Lutero e de Calvino.

Dessa forma, como parte desta conclusão, podemos afirmar que não foi o protestantismo que "inventou o capitalismo" como algumas leituras apressadas buscam demonstrar, mas sim que ele contribuiu para o condicionamento da produção histórica do desenvolvimento do seu tipo ocidental moderno. O santo protestante necessitava racionalizar de forma coerente a sua vida de ponta a ponta, observando a todo momento a sua conduta de vida através dos meios e dos fins, como forma de obedecer às ordenações divinas de ter uma vocação profissional e de desempenhar da melhor forma possível seu ofício - tudo em nome de honra e glória de um deus ausente. Esse fenômeno contribuiu para o afastamento do indivíduo da natureza: afastando-o de ter que se sujeitar as vontades oriundas do plano natural e mágico e condicionando-o a para ser educado para conformar o mundo de acordo com o seu ofício vocacional dado por deus. Para Weber, Lutero foi aquele que primeiro afastou a mágica do mundo de forma expressiva. Da mesma forma, foi aquele que primeiro buscou retirar a ascese monástica - como forma disciplinadora e racionalizada de vida - de dentro dos muros dos monastérios durante a Reforma. 0 reformador alemão esboçou, portanto, um tipo de teologia ascética intramundana, mas sem a caracterização rigorosa de uma autoinspeção constante.

A vocação profissional dos nossos dias se encontra deslocada das suas origens religiosas, pois não há mais o constrangimento da sensibilidade moral. Dentro deste 


\section{artigos}

\section{Lucas dos Santos Andrade}

quadro, a Igreja passa a ser uma eminente inimiga dos avanços do capitalismo e perdeu a sua posição de condicionante primordial dentro de um mundo que preza pela fé cega e laica do progresso, da ciência e da acumulação e produção de capital. Da mesma forma, a ideia, hoje tão comum e corrente e na verdade tão pouco autoevidente, da profissão como dever:

“(...) [é] uma obrigação que o indivíduo deve sentir, e sente, com respeito ao conteúdo de sua atividade "profissional", seja lá qual for, pouco importa se isso aparece à percepção espontânea como pura valorização de uma força de trabalho ou de propriedades e bens (de um "capital") (...)' (WEBER, 2005 [1904; 1920], p. 47)

Para nós, assim como para os indivíduos do tempo de Weber, a caracterização de uma ideia ética racional de valorização profissional não é estranha, pois já nascemos dentro do imenso cosmo dessa ordem socioeconômica. Estamos condicionados a viver presos dentro desta ordem, pois há todo um aparato racional de dominação burocrático em seu estado pleno manifestado através de leis e práticas sociais que nos mantém presos às práticas de relações do tipo capitalista moderno. Essa última característica funciona como uma espécie de couraça (ou rija crosta de aço, ou ainda jaula de ferro, na tradução de Parsons) ${ }^{16}$ que nos imobiliza e dificulta outras formas de relação econômica de forma expressiva, pois se o puritano queria ser um profissional, nós devemos sê-lo.

\footnotetext{
${ }^{16}$ Na célebre tradução de Parsons o termo foi traduzido para "ron cage", ou seja, jaula de ferro - tal tradução pode ser encontrada em diversas traduções para português que pegaram como base a tradução em inglês. Para a tradução brasileira da Companhia das Letras o termo escolhido foi "rija crosta de aço" (WEBER, 2005 [1905; 1920], 165). Contudo, acreditamos que qualquer uma das colocações respeita o objetivo do autor na busca de descrever metaforicamente e conceitualmente uma força de dominação que impossibilitaria que o indivíduo tenha 'movimentação'.
} 


\section{artigos}

O paradoxo protestante e o condicionamento do "espírito" capitalista ocidental de tipo moderno

\section{Bibliografia}

BOURDIEU, Pierre. Apêndice I: Uma Interpretação da Teoria da Religião de Max Weber. In: . A economia das trocas simbólicas. São Paulo: Perspectiva, 2007, p 79 - 98.

KALINOWSKI, Isabelle. Introduction. In: WEBER, Max. Sociologie de la religion. Paris: Flammarion, 2013, p. 7 - 69.

PARSONS, Talcott. Estrutura da ação social, vol. 2 - Weber. Petrópolis: Ed. Vozes, 2010.

PIERUCCl, Antônio Flávio. O desencantamento do mundo: todos os passos do conceito em Max Weber. São Paulo: Editora 34, 2013.

RINGER, Fritz. A Metodologia de Max Weber - unificação das ciências culturais e sociais. São Paulo: Edusp, 2004.

SELL, Carlos Eduardo. Max Weber e a racionalidade da vida. Petrópolis: Ed. Vozes, 2013.

SENEDA, Marcos César. Max Weber e o problema da evidência e da validade nas ciências empíricas da ação. Campinas: Ed. Unicamp, 2008.

SCHLUCHTER, Wolfgang. Paradoxos da modernidade - cultura e conduta na teoria de Max Weber. São Paulo: Ed. Unesp, 2011.

WEBER, Max. A ética protestante e o "espírito" do capitalismo. São Paulo: Companhia das Letras, 2005 [1904 - 1905; 1920]

. A ética protestante e o espírito do capitalismo. Petrópolis: Ed. Vozes, 2020.

. Ciência e política: duas vocações. São Paulo: Cultrix, 2018.

. Escritos políticos. São Paulo: WMF, 2014.

. Economia e sociedade, volume 1. Brasília: UnB, 2012.

. Economia e sociedade, volume 2. Brasília: UnB, 2015.

. Ética econômica das religiões mundiais - ensaios comparados de 


\section{artigos}

Lucas dos Santos Andrade

sociologia da religião, volume 1: Confucionismo e Taoísmo. Petrópolis: Vozes, 2016. - Ética econômica das religiões mundiais - ensaios comparados de sociologia da religião, volume 3: O Judaísmo Antigo. Petrópolis: Vozes, 2019.

- Metodologia das ciências Sociais. Campinas; São Paulo: Ed. Unicamp; Cortez Editora, 2016.

. Max Weber: ensaios de sociologia, organizado por: H.H. Gerth e C. Wright Mills. Rio de Janeiro: Ed. LTC, 1982.

- Max Weber: sociologia, organizado por: Gabriel Cohn. São Paulo: Ática, 2003. 